\title{
The Hispanic immigration in United States: an analysis of the relationship with the churches, employment and crime
}

\section{La inmigración hispana en los Estados Unidos: un análisis de sus relaciones con las diferentes iglesias, el mercado laboral y el delito}

\author{
Jesús Alberto Valero-Matas and Antonio Sánchez-Bayón \\ Universidad de Valladolid, España \\ Universidad Rey Juan Carlos, España
}

\begin{abstract}
The aim of this paper is to show the relationship among the Hispanic immigration (mostly with an irregular citizen status) in US (some areas where they live many Hispanic) and the churches that are linked to these communities. The undocumented Hispanics are being persecuted, deported and in the elections talk down them to win votes. Only in their confessions have they have found the most stable refuge for a long time due to during the past two decades, churches become in the main upholder and protector of the Hispanic community in the United States. Thus, this research explores the ramifications and the pillars of this outstanding relationship that had been built through time. This paper also analyzes the relationship between the labor market and unauthorized immigration, as it is attributed to unauthorized immigrants to be the cause of unemployment of the natives. As well as being criminals and the main inhabitants of prisons. Reality that is far from reality. The Trump Administration, following many of the thoughts of some American citizens, maintains the accusation towards Hispanic immigration of working illegally in the country, as well as increasing crime.
\end{abstract}

Keywords: Unauthorized immigration, congregations, Hispanic, labor market, crime.

\section{Resumen}

Este trabajo intenta analizar la relación entre la inmigración hispana (principalmente aquellos con un estatus de ciudadano irregular y en áreas donde residen muchos hispanos) en los Estados Unidos y las iglesias que están vinculadas a estas comunidades. Los hispanos indocumentados están siendo perseguidos, deportados y en las campañas electorales son criticados con el objetivo de ganar votos. Prácticamente, durante mucho tan sólo en sus confesiones han encontrado el refugio, pues en las últimas dos décadas, las iglesias se convirtieron en el principal defensor y protector de la comunidad hispana en los Estados Unidos. Por lo tanto, esta investigación explora las ramificaciones y los pilares de esta relación sobresaliente que se ha construido a través del tiempo. Pero también se aborda la cuestión del mercado laboral, pues se atribuye a los inmigrantes no-autorizados ser los causantes del desempleo de los nativos. Como también de ser delincuentes y los principales habitantes de las cárceles. Realidad que dista mucho de ello. La Administración de Trump, siguiendo muchos de los pensamientos de algunos ciudadanos norteamericanos, mantiene la acusación hacia la inmigración hispana de trabajar ilegalmente en el país, así como de incrementar la delincuencia.

Palabras clave: Inmigración no autorizada, congregaciones, hispanos, mercado laboral, delincuencia. 


\section{INTRODUCTION}

7 he huge loss of jobs suffered during the last decade by the native population is blamed on Hispanics, which is encouraged by Republican politicians. However, this loss must be attributed to the deliberate relocation policy applied by US companies Mexico, where labor costs are much lower and China.

The enormous fractures in the international system, the region has already incorporated new keys as a frame of reference: the decline of the US, the rise of China, the least regulatory influence of the EU, the greater self-esteem of the emerging powers and the crisis of legitimacy of international organizations.

There are several media outlets that (New York, Washington post, Foreign Affairs, PRI, New Yorker, etc.) say: President Trump's polarization policy towards his southern neighbors has seriously damaged US and US relations and has further accentuated regional fragmentation, enhanced by the consequences of globalization. Despite official statements to the contrary and presidential visits of a diplomatic nature, the willingness to develop intra - and inter-regional institutional cooperation is very limited.

As says Hirschman (2007: 6) each new wave of immigration to the United States has met with some degree of hostility and popular fears that immigrants will harm American society or will not conform to the prevailing "American way of life".

Trump in that eagerness to please his voters has taken actions of persecution and harassment of immigrants, thinking that his detention and deportation will give way to those positions being filled by the natives. There is already an antecedent with the braceros that did not follow that logic.

Some time, after the Migration raid in Mississippi, the largest that has been executed in a single state, some 300 immigrants remain in Immigration and Custom Enforcement (ICE) processing centers. The majority have not yet had the opportunity to defend themselves in front of a judge, as the authorities have not had sufficient measures so that these people can defend themselves. Which already indicates that accusation of distorters to immigrants.

For example, one of the detainees a few months ago, had been working for 14 years in one of the companies, cutting breasts and separating guts at the chicken processing plant in Morton, Mississippi and they took her arrested on August 7. That same day ICE assaulted seven headquarters of five pollera companies in different towns of the state and took with them 
687 workers, almost all of them were undocumented Hispanics. It is the largest migration raid in history in a single state (BBC, 2019).

This highlights how the US policy in that desire to meet the demands of a majority, which are not covered by objectivity, project different actions to accuse Hispanic immigrants, even when their workforce is necessary for the development of the country. And they do not hesitate to create myths that become viral in society. Even when it has no foundation and does not fit reality.

It is necessary to indicate, as some research centers point out (Pew, 2019) that Mexican immigration has been reduced, even many are returning, as they are also doing, immigrants from South America. However, immigration from Central America is increasing as well as from Asia and Africa. Hence the fear of Hispanicized of American society, as Trump argues, it is difficult (The Atlantic, 2016).

The objectives of the study presented here are to analyze, on the one hand, the differences between the SM and NSM and the change in objectives of the NSM versus the SM. The relationship between immigrants, mainly undocumented, with the sanctuary Movements and the different dominations. How churches collaborate with immigrants. Second, to debate the everlasting problem that Hispanic immigration takes jobs away from those born in the US. And finally, to discuss the criminalization of immigration.

\section{Sanctuary Movement and New Sanctuary Movement}

In the 80 s of the last century the sanctuary movement was born in order to give refuge to the citizens of Central America fleeing civil conflicts. In response to the migration policies that hindered the asylum of these citizens of Central America. Given this reality, a large number of religious congregations chose to declare themselves religious sanctuaries and pledged to provide shelter, food, etc. and, often, legal advice to Central American refugees. Among the denominations that joined were Lutherans, the United Church of Christ, Catholics, Presbyterians, Methodists, Baptists, Jews, Unitarian Universalists, Quakers and Mennonites.

Sanctuary activists argued that because many Salvadorans and Guatemalans was fleeing the conflict and ravages of civil war in their homelands, they were political refugees who met both international and U.S. domestic criteria for refugee status. Subject that the Reagan administration denied them, arguing that they were economic immigrants, therefore they do not have access to refugee status (Kerwin, 2015). 
Those who participated and united the movement with their behavior were defying federal law, which implied arrests and trials during this decade of significant people from the sanctuary congregations. This reaction to the politics of the roots of the movement derive from the right of sanctuary in medieval law and Jewish and Christian social teachings. This had its greatest significance during the Reagan administration that raised the persecution of undocumented Hispanics (Bezdek, 1995).

All this is not new since sanctuaries are necessary to go back to ancient Rome when Christian temples were a refuge for those who practiced Christianity, criminals etc. During the Middle Ages, Christian temples once again become protection/ shelter for the persecuted. As he says Shoemaker (2013) The practice of church sanctuary continued in mediaeval Europe, granting protection to murderers, thieves, and other criminals from worldly authorities

In the case of the US, they begin to emerge, following European medieval models, space for refuge and reception of slaves, during the Civil War when the first practical provision of anything like sanctuary occurred in the years before the Civil War (Adkins, 2014). The Underground Railroad came into being to help slaves flee the South and find safety in many congregations throughout the country. In the early 1970's faith communities opened their doors to conscientious objectors who'd been drafted to the Vietnam war.

The Sanctuary Movement remained latent until 2007, and woke up for the increase by persecution and expulsion actions of undocumented immigrants. They made a comeback with strength during the Obama administration of mass deportations, and this to an even greater extent since Trump administration and this is explicit in the many New Sanctuary Movements (NSM) that have formed in recent years (see, e.g. New Sanctuary Movement of Philadelphia, National Sanctuary Collective, New Collective Coalition, among others). This collective action was strong and spread rapidly because as they say Carney et al. (2017: 18) the key point here is that, when combined with the fierce and durable commitment to the support of refugees and the undocumented, these $a d-h o c$, cross-border, multiply-scaled sanctuary networks produce a flexible and highly successful strategy of resistance that expands and contracts as needed.

It is necessary to highlight two substantial differences, one, the group on which the movement was focused. As he writes as Bauder (2016: 3) says: The NSM shifted focus from newly-arrived refugees to illegalized migrants who have been present in the USA for a longer period and now 
call USA cities their home. Thus, urban sanctuary policies and practices in the US increasingly focused on migrants who seek to maintain the "quotidian, ordinary life they have built" (Caminero-Santangelo, 2013: 96) rather than refugees fleeing from war, violence, and terror. In other words, the NSM has emphasized the need for safety for individuals and families who already are de-facto members of urban communities. And two, while the SM were collective actions in unison, the NSM works with different voices, that is, each movement acted independently. There was no all together.

As indicated above, the objectives of the last century were some and now are others, and this has been influenced by a series of factors resulting from a diverse range of social and geo-political conditions.

If in the past there was talk of sanctuary churches, which responded to a goal. Now, due to the dimension of the phenomenon and the extension of the objectives, it has been extended to sanctuary cities. Sanctuary City is as much a process as a goal (Walia, 2014).

It was in 2014 with the shelter of Daniel Neyoy Ruiz, upon entering Church Sanctuary in Southside, which ignited the rebirth of the Sanctuary Movement. After living in the sanctuary for 28 days, Daniel was granted the suspension of deportation and was able to safely return to his life in Tucson. Congregations continued to have their commitment as Shrines for these undocumented people. It was with the Trump Administration when they have been fired again by immigration policy. So, the denominations that maintain their Sanctuary Pledge have seen their activity increased since then.

An important aspect to understand the phenomenon from a comparative historical retrospective is the difference between the SM and NSM, which is very important to study and analyze the matter.

While the Sanctuary Movement (SM) of the 1980s was mobilized by religious congregations, and although as says Summers (2018) religious congregations set the stage for continued activity today. These congregations demonstrated that they had a dual — and corresponding - responsibility as places offering refuge and participating in nonviolent resistance. The New Sanctuary Movement has expanded the fate of Sanctuary jurisdictions (cities, counties, and states), participants in the NSM have put into place micro-innovations at the local level, take part in public actions, acquiring a threefold commitment to advocacy, accompaniment, and action.

As Freeland notes (2010: 490) according to described by analysts as Golden y McConnell (1986) the sanctuary movement of the 1980s was a network of groups working for a common cause, ultimately organizing and 
coordinating efforts. Mirroring the SM, the NSM is a coalition of interfaith religious leaders and their congregations who have come together to respond to injustices suffered by undocumented immigrants living in the United States.

Both movements (SM or NSM) both have been perceived by the different administrations, as a social challenge to their immigration policies and many sanctuary workers perceive their work as religiously inspired and founded. It is for this reason that the dimension of the Sanctuary churches is greater and the Trump administration perceives it as a threat to their political interests. Under the prism of faith, there is no dogmatic fracture as can happen with politics, since religion predominates the act of helping others.

As in any analysis, study or research, it is necessary to know the main reasons why these people leave their countries. It is not pleasant to leave a country, where he has his family and friends, and significantly when you go to another where you do not know the language, they are found irregularly, with the permanent danger of expulsion, low wages and no social security. That when they arrive in the country, but before, they have had to pay the coyote, go through difficulties and even lose their lives. All this accumulation of realities and many others are not a clear exponent to undertake the adventure, in many cases of the non-return of the "American dream". In other words, a better, safer, healthier life for people everywhere.

Looking at the Figure 1, the main causes of Hispanic immigrants do so because of violence, as expressed by 50.4 percent. While 23.10 percent do so for poverty and another 22.7 percent leave the country in search of an opportunity, basically work that allows them to develop in the US, give a better quality of life to their children and send remittances to their country.

On the other hand, the migratory causes vary and not always, the migratory factor is due to violence (see Figure 2). None of those consulted from Argentina and Chile have declared emigrating due to Violence, instead they have stated that they emigrate due to job opportunities, but also due to poverty. It should be remembered that when the SM emerged, in the decade of the $80 \mathrm{~s}$ of last century, then they declared that the main cause of leaving the country was violence. So these countries were under military dictatorships. In contrast, Guatemala, Honduras, El Salvador and Mexico say that the main cause of migration is violence. In the three Central American countries, homicide rates have been consistently high over the past two decades, even compared to those in countries facing armed conflict. 
The Hispanic immigration in United States: an analysis of the relationship with the churches ... / J.A. VALERO y A. SÁNCHEZ

Figure 1: Main Causes of leaving the country

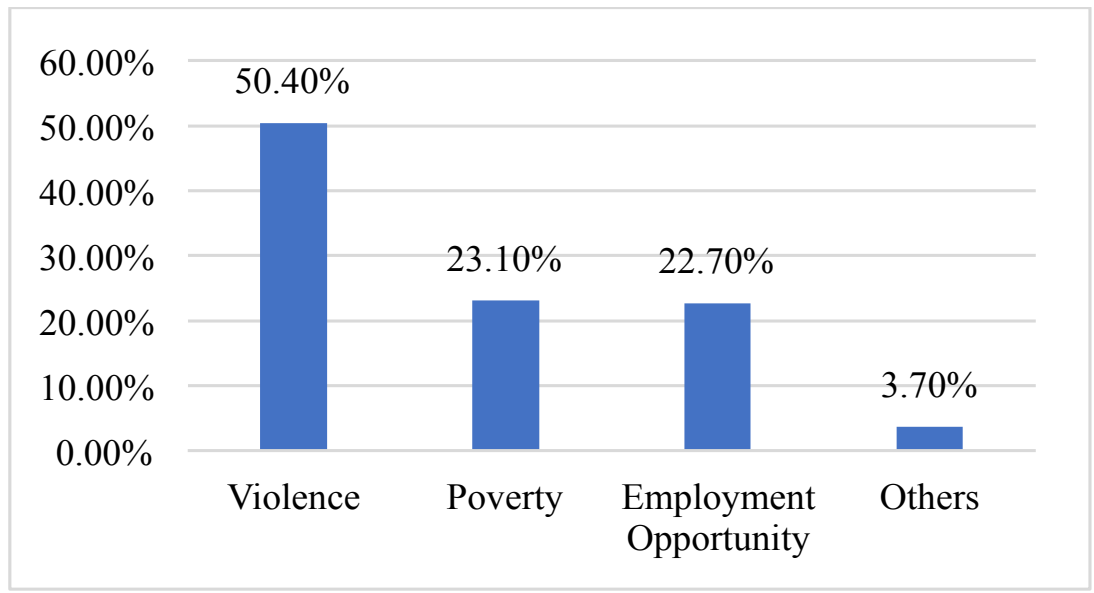

Source: Own Elaboration.

Figure 2: Causes of leaving the country

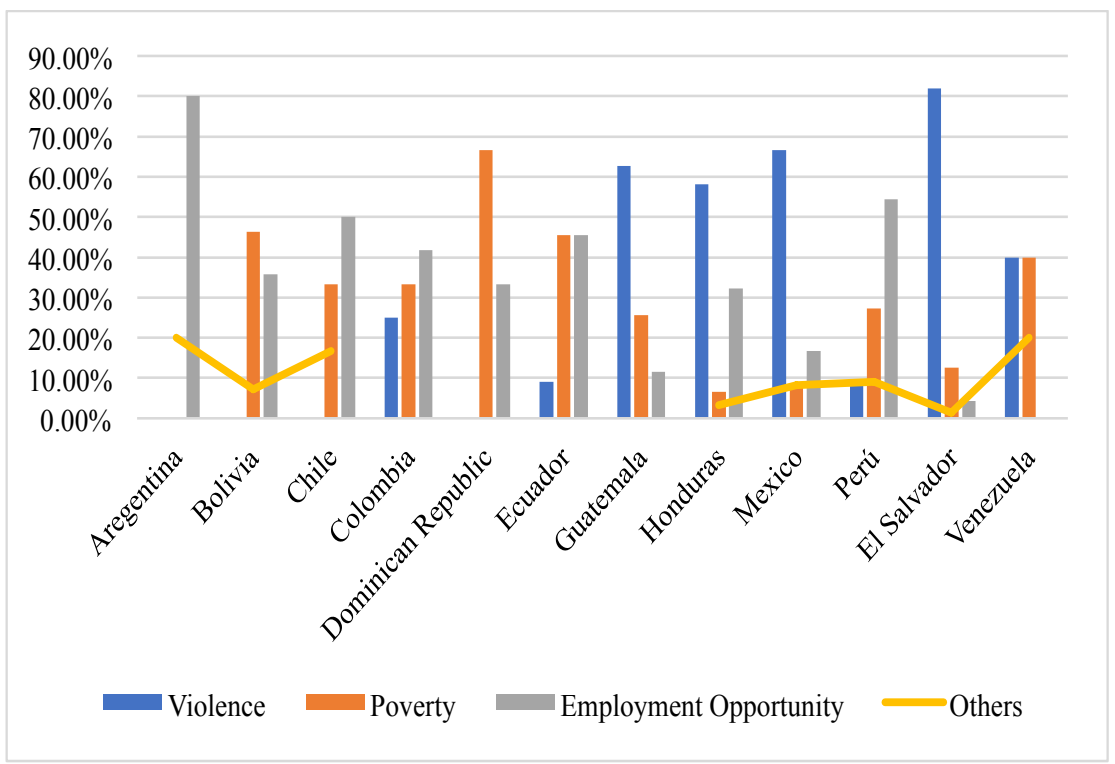

Source: Own Elaboration. 
As Prado (2018) points out, the violence registered in the Central American Northern Triangle (TNCA) has been attributed above all to criminal groups known as "maras". While in Mexico, violence is multi-causal, drug trafficking, lack of opportunities, poverty, corruption, etc. As Odriozola and Cervantes (2021) indicate that Mexico is in an armed conflict, between drug trafficking groups and other groups that are fighting with the Mexican State. And current policies have not diminished the problem (López-Santiago et al., 2017). This leads to many Mexicans leaving the country. However, according to PEW (2019), Mexicans leave the country, but in fewer numbers than in past decades. In the rest of the countries, poverty dominates the main cause of leaving the country.

Given these facts, religious communities become a point of support for these migrant communities, who only want a better life for themselves and their families. The constant threats of the Trump Administration, the churches have opened their arms more to the protection of immigrants. As the bishop wrote Nicholas DiMarzio: Diocese of Brooklyn. It offered comfort and support to the many immigrants - documented and undocumentedwho find themselves ... in a miserable condition because of a change of the administration of our nation which has threatened many with deportation". It pledged to protect and advocate for immigrants, particularly those with US-born children. "We will always welcome the stranger amongst us, no matter what your legal status," it said, because the "Law of God takes precedence over human laws, and to this we must be witnesses.

Similar responses have been from other denominations. Like the Presbyterian Community Like the words of Rev. Allison Harrington in the Huffpost to the journalist Sarah Ruiz-Grossman (10/20/2017) It's not enough to say, 'Come to our house of worship and you'll be safe. We have to also work in our communities to make sure people are safe in their workplaces, in their homes.

For this denomination, it does not imply filling in a box at the national level and being labeled as Sanctuary Church, but it is also necessary to get involved, act and ensure that these people cease to be a negative element for American society. For many Presbyterian reverends, it is necessary to act to end the whiteness and prestige that has dominated the US for decades. This is one of the reasons on which many of these Sanctuary Church are built, the help to others demanded by God.

Evangelical denominations are also active in the defense of unauthorized immigrants, of welcoming them in temples, and supporting them to achieve legalization in the country. Last August (2019), ELCA Churchwi- 
de Assembly held in Milwaukee has declared itself a 'sanctuary church body,' signaling support for immigrants.

Other evangelical denominations also very active in these activities of refuge and protection, for reasons not only religious and humanity, but also for a common identity. As he says Eguizabal (2019) the majority of Latinos who immigrate to the United States bring with them their cultural values and religious identities. A high percentage of them are Christian evangelicals, who have left behind their home churches. Many of them have transplanted their worship and liturgical practices and have established churches that resemble their home country churches and culture. (...) Latinos show a strong evangelistic fervor and commitment to missions. It is worth noting that when a Latino Protestant congregation is established it immediately becomes a church in mission. Latino churches in the US are making a noticeable impact through mission work within the country as well as worldwide.

In this behavior of refuge and upholder for Hispanics in the US, who are being persecuted and expelled by the different administrations, and now by the Trump administration, a spirit of kindness and support to the needy prevails in the denominations, and the moral and social responsibility of the denominations cannot be ignored. As he writes Kerwin (2017), The Church seeks to create conditions that allow all members of the society to flourish (the common good), to foster "right relations" between community members (justice), and to build unity between native and immigrant communities based on the shared, life-giving values embedded in their diverse cultures (communion). The effectiveness of Church institutions as integrating agencies requires solidarity. Solidarity, in turn, demands presence and accompaniment, and, which is the "nitty gritty care for the marginal".

As the perception of threat continues, persecution will increase, and so will the "hatred" of immigration, especially the Hispanic community (Sánchez and Valero-Matas, 2020). If it continues, Sanctuaries in churches, cities or counties will increase. It should not be reduced to a religious question, also, it is a work and social reality. The Hispanic workforce is necessary and fundamental in the North American labor market. It is cheap work that increases American economic growth, and this has no social cost for the States and the Federal Administration due to their undocumented status. Another aspect to highlight is in the religious question. Christianity is declining with the natives as it grows with immigration. This is causing many Christian denominations to maintain their membership number and others to prevent their disappearance. Martínez (2018) points out 
that with the exception of "Asian American-based denominations, the few US Protestant denominations (and the Catholic Church) that are growing are growing because of Latinos" (2018: 202). If the trend continues, these churches will find fewer Anglo and more Latino members among their congregations. Then they should ask themselves how much participation in their congregations will they give to the Latino members?

\section{Source OF DATA}

The data for the analysis of religious behavior and its relationship with the churches come from a survey of Hispanic immigrants, mainly in the federal triangle. The incidental sample of the quantitative study was carried out on 1,432 people, with a response rate of 78 percent. Surveys were conducted only for unauthorized and authorized immigrants (with green cards) in the Federal Triangle: DC, Virginia and Maryland. The distribution was 49.2 percent in Virginia, 38.5 percent in Maryland, and 12.3 percent in DC. The profile of the immigrant was: 6.2 percent university studies, 24.1 percent secondary studies, 61.4 percent primary studies, and 8.3 percent without studies. Surveys were also carried out among those responsible for religious centers in order to know the reality of immigrants and their relationship with the congregations.

A closed structured questionnaire was used for data collection. This was applied in churches and religious centers, meeting places for immigrants and public adult education centers, from March to November 2019. The operationalization of the variables resulted in six distributed blocks: personal data, time spent in the USA. Family structure, relationship and religious practice and employment situation and knowledge of English. All were interviewed in their mother tongue. The information analyzed here comes from questions respondents were asked about their beliefs and practices before going to the United States and after coming to the United States.

To analyze the reliability of the sample, the Cronbach's Alpha analysis was chosen for its ability to measure the stability and consistency of the groups of likert variables (González Alonso and Pazmiño Santacruz, 2015; Seifert, Hervás Gómez, and Toledo Morales, 2019). The value of Alpha for the whole questionnaire was $\alpha=0.83$, widely exceeded 0.7 , so the variables present good reliability (Tavakol and Dennick, 2011). The choice of the quantitative methodology through a questionnaire responds to the descriptive purpose of the study, which is the most suitable due to the referential nature of the information it collects. 
The Hispanic immigration in United States: an analysis of the relationship with the churches ... / J.A. VALERO y A. SÁNCHEZ

Once the data was collected, we proceeded to the systematic tabulation process and the debugging of the database to allow its correct analysis. Data processing was performed using the SPSS version 26 statistical program. Due to the nature of the study, the analysis was mainly descriptive (frequencies and descriptive).

\section{RELIGION AND IMMIGRATION: THEIR RELATIONSHIPS}

Religion in the world of the migrant is very important, specifically in the USA. Since the church is transformed into a space of welcome, formation, integration and catapults it to the market. The migration process, especially Hispanic, involves a process of reaffirmation of the faith. In other words, it implies an experimentation of core belief, as Levitt (2003: 251) says religion plays a crucial role in the construction of identity, in the production of meanings and in the formation of values.

Following with Levitt (2008) religion is an underutilized positive force that scientists and social activists can no longer afford to ignore. It cannot be ignored that the churches, particularly the Catholic and Protestant, are organized into groups that serve for social action as a policy to defend the civic and religious interests of immigrants (2008: 766). For contemporary immigration, religion continues to forge a cultural identity and social purposes. Many of the congregations attended by immigrants are perceived in the area as a particular service of the ethnic-cultural group: religious practices are often carried out in their own languages excluding natives born in the USA. This is due to two issues, on the one hand, the ignorance of English by many of the Hispanic immigrants. Therefore, they need the religious celebration in their language. Second, Anglo-Americans favor the formation of Hispanic religious communities within the denomination itself, distinguish between Anglo and Hispanic participation. Thus, two identical religious communities are generated in the same space separated by language (Valero-Matas and Sánchez, 2018). Perhaps for social and cultural reasons, and to a lesser extent theological, they fear that the different ethnocultural values occupy the banks of their churches. Religions are not limited, therefore, to preserve and transmit ethnocultural identity, but to transform it. Influencing in the central way in which immigrants adapt and transform themselves in the social inclusion process in the receiving society (Ambrosini, 2008: 20).

The fear of cultural change due to Hispanic values is a product of political discourse rather than reality in the US. Hispanics try to preserve their cultural values, within an American cultural context, and They do not want 
to transform American culture. Their difficulty in learning the language, the undocumented status, the rejection of the Anglo-American population, an so on, leads them to seek a "social shelter" that allows them to live in the US. The different churches seek a balance between the difficulty and the need of Hispanics, facilitating their integration and coexistence in North American society. At no time, neither the churches nor Hispanics want cultural change, but rather interaction with the dominant culture without losing part of their identity elements.

On the other hand, in the case of the Christian religion, reading the bible in (Lev, 19: 33) says, they fled persecution, suffered in exile, and ultimately returned home. From this experience, they learn to love and empathize with refugees and immigrants' Critical denominations have an obligation to give help, support and asylum to those in need. This projects closer relationships between those in need and the different denominations. In order to learn about highlights in this relationship of immigration and churches, an investigation (2016-2018) was conducted in different churches and meeting centers for Hispanic immigrants. Different items related to the analysis under study are expressed below.

\section{Attendance at religious Services}

Assistance to religious services is a source of integration is also an act of reaffirmation of culture, as suggested by Hirschman (2004): religious events and practices are not only rituals of faith, also of popular religiosity proclaiming acts of cultural reaffirmation of belonging To an ethnic community. In addition to these observations, it should be noted that the church in the USA. Becomes a form of expression, especially for irregular immigrants who have no voice or vote.

The tabulation revealed that the majority of Catholics attend religious services, mainly Sundays and feast days, as recorded by 44.5 percent. Secondly, there are those who attend once a week and as shown in Figure 3. While a group appears that occasionally participates (1.8 percent).

In the case of evangelicals, their attendance ( see Figure 4) at religious services is conditioned by labor reasons: many of them, as they said, are forced to work on Sundays, which greatly conditions their attendance at worship. But they remain a commitment of Hispanics with their belief and religious community. 
The Hispanic immigration in United States: an analysis of the relationship with the churches ... / J.A. VALERO y A. SÁNCHEZ

Figure 3: Frequency of attendance at religious services (Catholic)

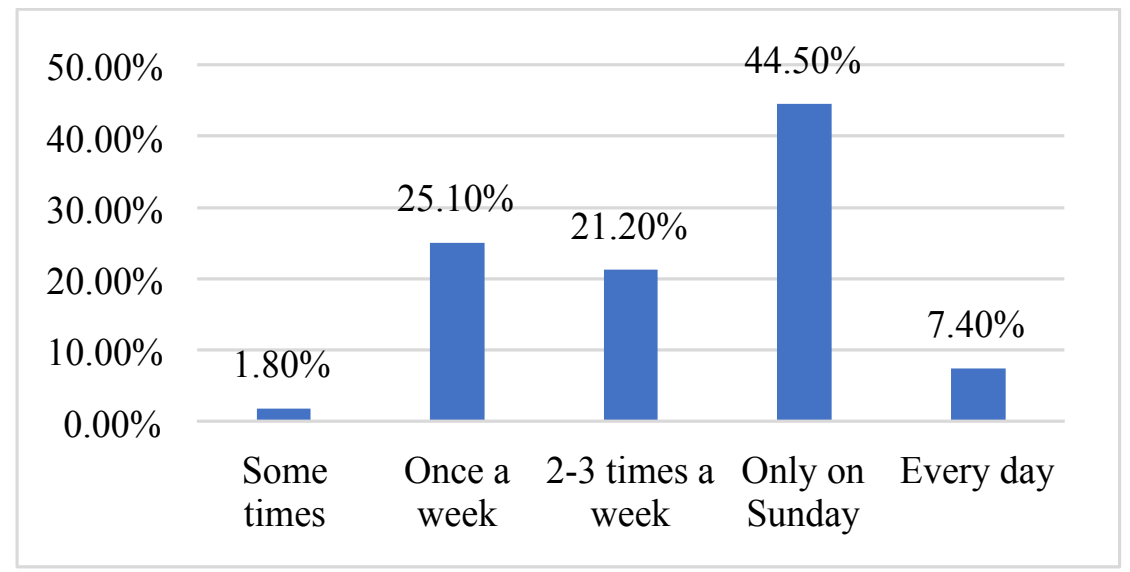

Source: Own Elaboration.

Figure 4: Frequency of attendance at religious services (Evangelical)

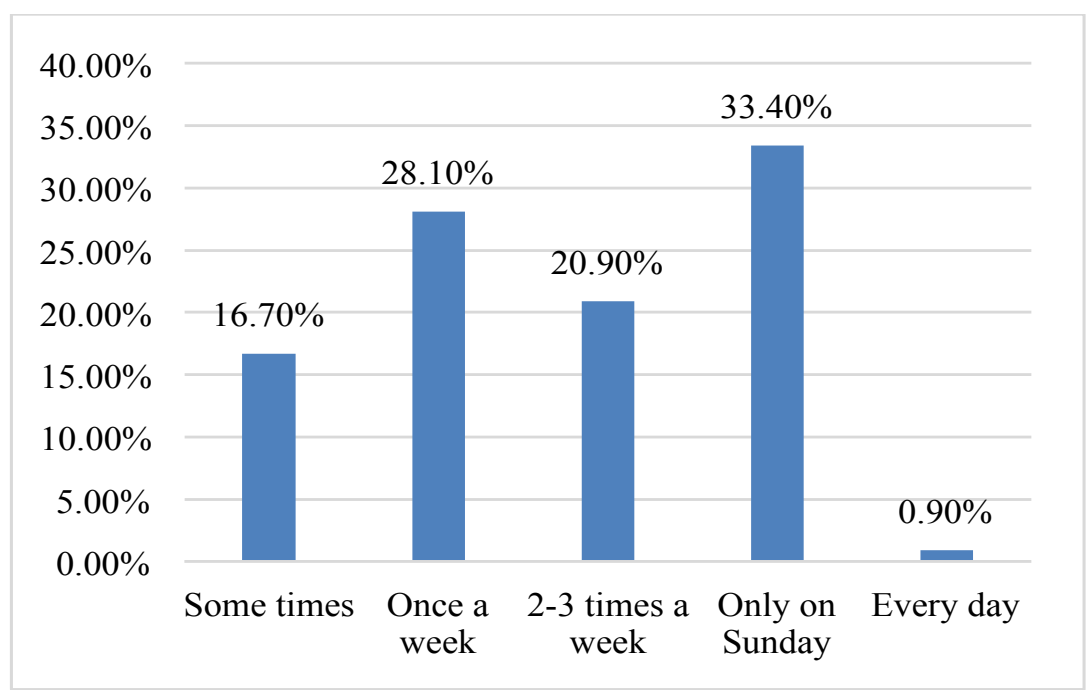

Source: Own Elaboration. 
Figure 5: Frequency of attendance at religious services (Protestant)

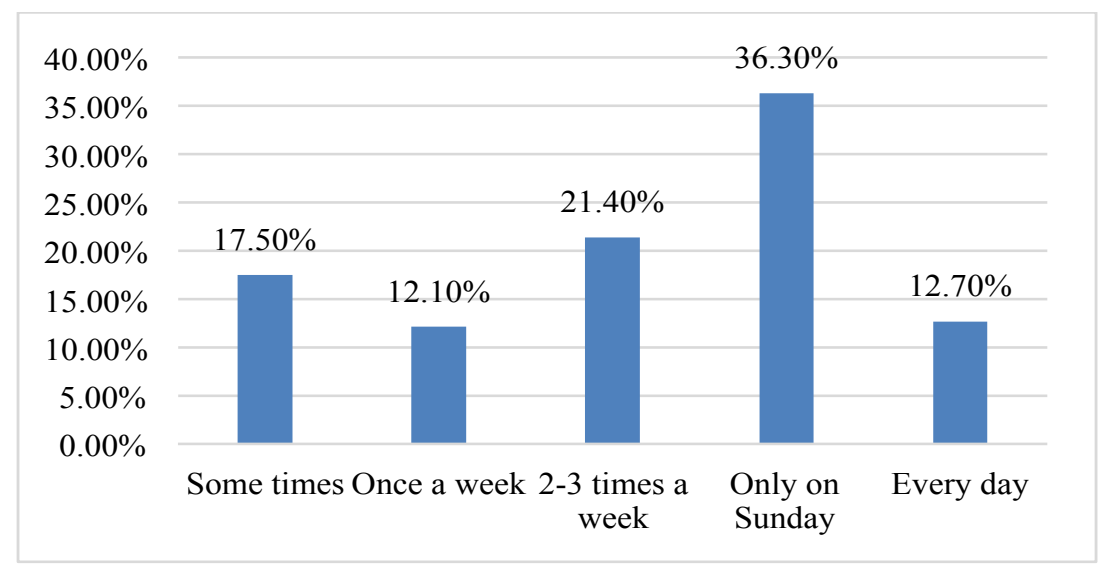

Source: Own Elaboration.

The $36.3 \%$ of the Protestants (see Figure 5) who have answered the questionnaire say they go to religious services only on Sundays, while $21.4 \%$ go two or three days a week. Although, the participation of the latter in community activities lies in reading the Holy Bible, improving the facilities of the tabernacle and in the assistance groups for those in need. Others highlight that they would like to attend church more and sometimes do it, due to difficulties such as distance to the temple, attention to family members, and the job.

These religious communities operate at the micro level and contribute to the formation of ethnic communities, which could design closed and self-referential communities (Valero-Matas and Sánchez, 2018). But they also help to connect its participants and assistants to parishes and ethnic / national communities to wider networks in the public space, which are not necessarily limited to the religious (Rivera-Sánchez, 2007: 265).

Participation in a Catholic, Orthodox or Protestant church implies that immigrants identify with religious beliefs and practices, and to what extent you are supporting them in their first contact with the country. According to Díaz (2006: 100), most immigrants are assimilated by the dominant culture, leaving their culture behind; however, Hispanics do not undergo this process, questioning this theory. For this author, this happens, because Hispanic immigration takes shelter in faith, and places of cultural defense are formed in religious centers. In other words, these are places for meeting, exchange and Hispanic cultural manifestation, which cannot be done in 
other contexts. Churches with a Hispanic apostolate are used to protect newly arrived Hispanics from the abandonment and insecurity of being in a foreign country.

This Hispanic behavior has not been analyzed from a context of "self-protection", but from a debate, mainly, focused on whether the participation of immigrants in congregations produced a "bridge" that promoted the assimilation of immigrants or a "limit" that inhibited it. (Warner 1997; Cadge and Ecklund 2006). Reinforcing Smith's (1978) idea that immigration was a "theological experience". When reality is not only a theological issue, but due to its ability to cement the Hispanic immigrant population, it is observed as a dominant social fact.

Among immigrants, religious participation is also likely to be affected by conditions at the place of destination, including the share of co-religionists, the proportion foreign born, and the diversity of local religious beliefs (Connor, 2009a). Although Stark and Iannaccone (1995) argue that religious diversity promotes greater competition for adherents and thus higher rates of participation, evidence on this topic is mixed (Chaves and Gorski, 2001) and studies among immigrants generally find a negative relation between religious diversity and participation within areas of destination (Connor 2009a, 2009b; Tubergen, 2006).

It should be kept in mind as they say Valero-Matas and Sánchez (2018) unauthorized Hispanic immigration, they are a citizenly invisible immigration, while it is a visible labor immigration. For this reason, rituals and celebrations as practices of religiousness, allow them to create alternative forms of expression and belonging, qualities that also result from memory, as well as forms of remembrance and return to the place of origin. Hence, participation in the activities of the denomination, support for other equals is important, as it entails a reinforcement of their identity, but also protection against possible expulsions. Establishing a kind of "invisible community." That is visible in the workplace and religiously, but not in the generation of ties of action and response to deportations that develop along the lines of affectivity and trust.

This graph indicates that as an immigrant acquires less commitment to his participation in church activities than when his situation is unauthorized. You cannot blame your situation of legality, it may be a factor, but that it requires more work, acquires other responsibilities and has less time to collaborate daily in the church. Work and space mobility also conditions being able to help in the church. 
Figure 6: Do you help in the church?

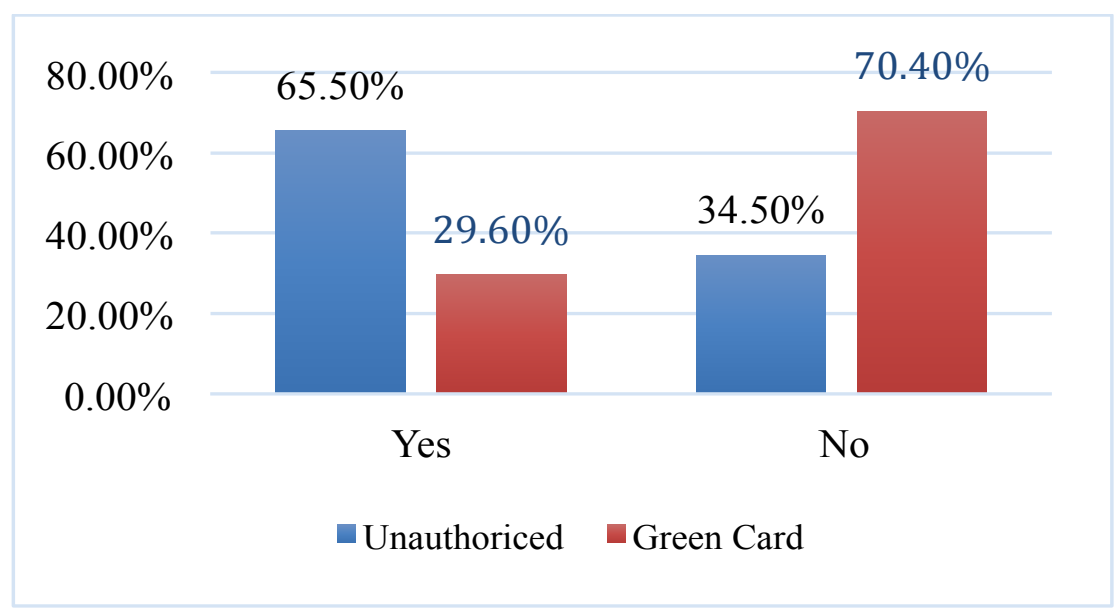

Source: Own Elaboration.

\section{TyPES OF AIDS}

One of the important aspects to know the relationship of people with an entity, whether social, political or religious is the link between the institution and people. The situation of immigrants in the US is complex, and many of them due to their training and others, are in a complicated situation. Given their reality, they approach churches or social aid associations that have denominations. The type of help configures the situation of immigrants in the US.

Analyzing the Figure 7, two issues are observed, which most of the authorized immigrants.

They do not receive help, although there is a 15.5 percent who go to learn English and thus be able to improve in employment, while 11.3 percent go for assistance. 73.2 percent receive no help. In the case of the unauthorized, the issue is complicated. 28.1 percent do not receive any help, but these include those who have no connection with the churches, either because of their beliefs or because they have not approached them. Among those who receive aid, 25 percent do so due to need for care, food, health, school support, etc. 18 percent do so to learn English and 16.40 percent to obtain the Visa. 4.7 percent are welcome in some church. Only the option of an answer was given, but speaking with them, the aid is usually concatenated, that is, when they go to a church with resources, not all of them have 
resources, the aid is mainly to obtain a visa and learn English, but there are others because of their precarious situation and request assistance.

Figure 7: Aid received by denominations according to administrative status

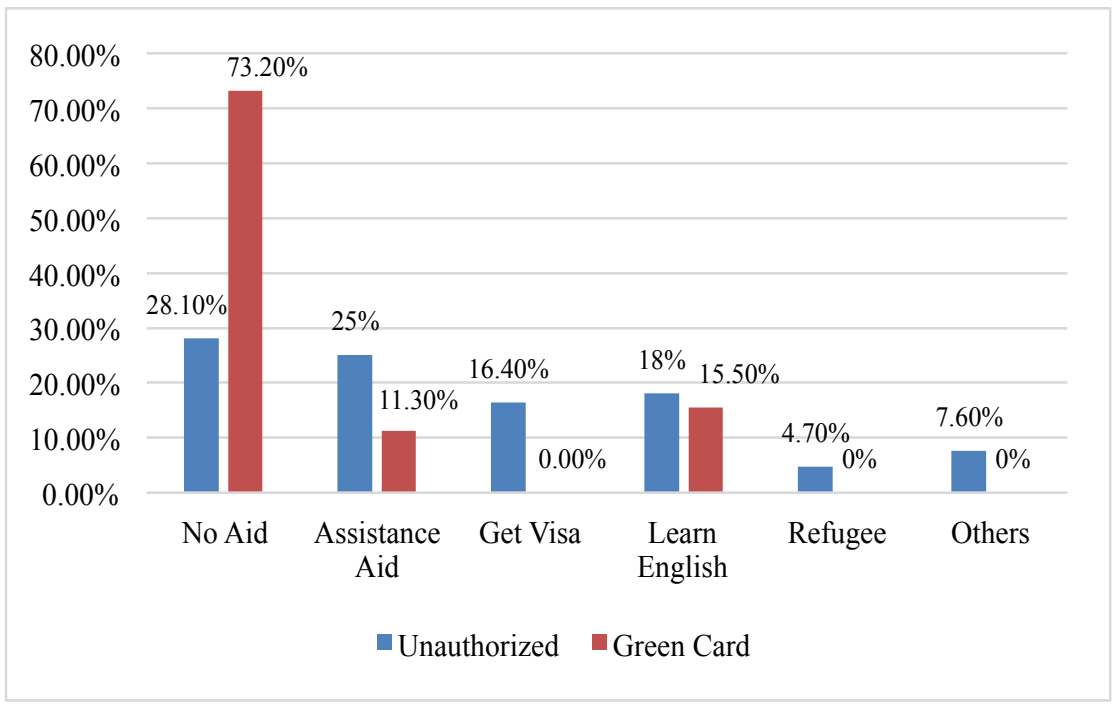

Source: Own Elaboration.

\section{IMMIGRATION: WORK AND UNEMPLOYMENT}

As mentioned earlier, one of the most prominent elements of the Trump administration's accusations against the unauthorized Hispanics is that they take the job from the Americans, increasing native-born workers unemployment. As different studies point out, immigration is beneficial for US in all its dimensions, that is, not only immigrants with high educational level but also low-skilled immigrants. On the other hand, if immigration were authorized even more, avoiding problems for both parties. Aviva Chomsky wrote in They Take Our Jobs (2007), that one of the myths about immigration was that our jobs are taken away. But this is false, despite the Trump administration holding it to keep its voters happy.

As Acemoglu (1998) expressed in his work, bracero exclusion does not affect wages within the diversification cone because any fall in the labor-land ratio only raises the fraction of farmers using the advanced technology, without changing the marginal product of labor. Firms adopt the technology that emphasizes the factor whose relative supply has risen, wi- 
thout any necessary change in the price of the factor whose relative supply has fallen.

Along the same lines is the research carried out by Michael A. Clemens Ethan G. Lewis Hannah M. Postel (2017: 31) where they conclude that bracero exclusion failed to raise wages or substantially raise employment for domestic workers in the sector. The theory of endogenous technical change suggests a mechanism for this null result: employers adjusted to foreign-worker exclusion by changing production techniques where that was possible, and changing production levels where it was not, with little change to the terms on which they demanded domestic labor. These authors also in their work, signed the statement by William E. Martin where in one of his studies he emphasized that the exclusion of braceros workers involved the hiring of domestic workers was false, since it was replaced by technology by way of Recover production without a higher cost (2017: 30).

Many other studies conducted by economists show that immigration, whether legal or unauthorized, is a benefit to the US economy and has a direct impact on improving the jobs and wages of domestic workers. A research carrier out by Professor Peri together with Professor Sparber (2009) showed that the most disadvantaged groups of Native Americans experienced a significant change as a result of the arrival of low-skilled immigrants. Arguing that Immigrants with little educational attainment have a comparative advantage in manual and physical tasks, while natives of similar levels of education have a comparative advantage in communication- and language-intensive tasks. Native- and foreign-born workers specialize accordingly. When immigration generates large increases in manual task supply, the relative compensation paid to communication skills rises, thereby rewarding natives who progressively move to language-intensive jobs.

A recent NASEM study (2017) and edited by Francine D. Blau and Christopher Mackie confirms that immigration has no negative effects on overall wages and employment of native-born workers in the longer term. It is also extracted from it, which high-skilled immigrants, especially in technology and science, who have come in larger numbers in recent years, had a significant "positive impact" on Americans with skills, and also on working-class Americans. They spurred innovation, helping to create jobs. The report emphasizes that immigration is essential for the economic growth of the US, because immigrants bring new ideas and join a US workforce that would be reduced without them, helping to ensure continued growth in the future. 
The arrival of new immigrants does not directly affect the jobs of domestic workers, as they write in a paper Ottaviano and Peri (2012: 34), "Despite being a very important part of the workforce, immigrants have had no effect even on native jobs or native wages". The group suffering the biggest loss in wages is the contingent of previous immigrants, who compete with new immigrants for similar jobs and occupations. Finally, there is no model that demonstrates the negative effects of Hispanic immigration on the wages of U.S.-born workers. Neither does the influencial model by Borjas (2003) ${ }^{1}$ implies that it is hard to claim that immigration has been a significant determinant in the deterioration of the wage distribution of U.S.-born workers during the period 1990-2004. The study by Peri and Yasenov (2019) also found no evidence of negative effects. Because the point estimates in most of the samples using the May-ORG data are slightly positive and do not suggest any negative impact on wages of USborn workers. Certainly, there is no consistent evidence of large negative efects such as the ones presented in Borjas (2017). According to the study by Ottaviano and Peri (2012) in the long run the average wage of U.S.-born workers experienced a significant increase $(+1.8$ percent $)$ as a consequence of immigration during the 1990-2004 period. Even in the short run (as of $2004)$ the average wage of U.S. native workers increased moderately $(+0.7$ percent) because of immigration.

This confirms that immigrants with low qualifications, as was the case with immigrants from the bracero program, on the one hand, come to fill some jobs that the natives-born workers do not want, and therefore necessary for the survival of the American economy. Well, as PEW (Figure 8) points out, immigrant profiles are very localized in areas rarely visited by natives. In addition, unauthorized immigrants earn a salary well below the average salary in the US.

According to the data of this Think Tank, approximately 30 percent of the miscellaneous agricultural workers, 31 percent of the installers of drywall and tiles and 28 percent of the classifiers and classifiers of agricultural products and 23 percent of the operators either They were documented. And 12 percent of miscellaneous personal-looking workers, beauticians and makeup artists, were undocumented. That is, they perform jobs that are very badly paid and, as has been said, are jobs that native-born worker do not want. In addition, immigrants, especially those not authori-

\footnotetext{
${ }^{1}$ Argued using national data from five decennial U.S. Censuses (1960-2000) that U.S. workers lost, on average, about three percent of the real value of their wages due to immigration over the period 1980-2000 and that this loss reached almost nine percent for native workers without a high school degree (Borjas, 2003, Table IX, page 1369), at least in the short run.
} 
zed, are those who care for the elderly, among other problems because they have a poorly paid jobs and nobody wants them.

Figure 8: Pew Research Center (2019)

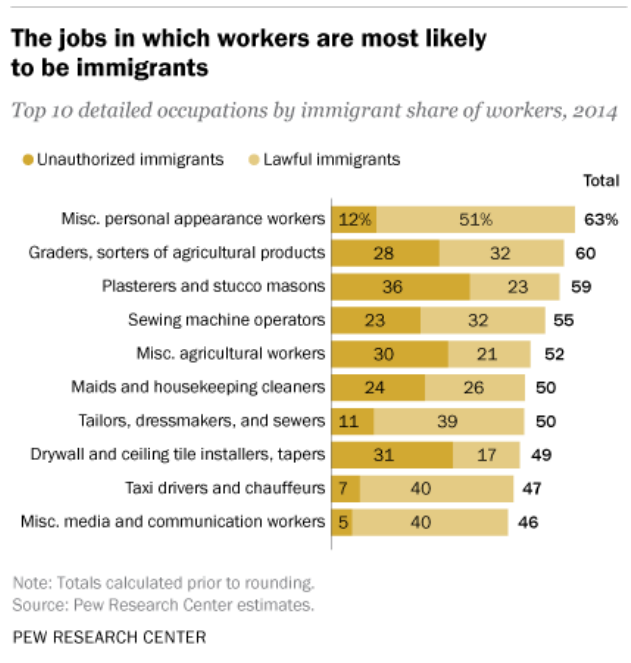

Immigrants represent 17 percent of the US workforce, according to the U.S. Bureau of Labor Statistics (May 16, 2019). This does not imply in the opinion of economists that immigrants are taking the jobs of Americans, but rather are completing them. So, it is the opposite of what Trump says. But few experts believe they are taking jobs from Americans, as Trump says. As some American economists argue, immigrants come to cover jobs that the natives do not occupy. Therefore, instead of being a problem they are a solution. US need hand to fill many of the jobs, and not only unskilled, but also qualified jobs, as described Hisrchman (2007: 10) The demand for immigrant labor is not restricted to unskilled manual labor. The United States and other industrial countries have encountered a shortage of scientific and engineering workers, particularly in the high-tech sector.

Because of the religious nature of the sanctuary movement, it is not surprising to see the "clergy" among those giving the most time to sanctuary activities. For them, sanctuary is seen as part of their ministerial duties. The percentage of the "professor" category, when compared to the other category percentages, is consistent with McCarthy and Zald's account of activism: professors are among those most likely to give time to the move- 
The Hispanic immigration in United States: an analysis of the relationship with the churches ... / J.A. VALERO y A. SÁNCHEZ

ment. Some other "professionals", however, are noticeable by their absence across the categories of the dependent variables. (1991: 1000)

\section{CRIMINAL IMMigRation: A MYTH}

Myths and stereotypes about immigrants and crime often provide the basis for public policies and practices. These stereotypes spread through movies and television series that project a lasting image. of immigrant communities permeated by criminal elements. In addition, the media have been full of stories of violent crimes committed by the Italian mafia, Cuban Marielito's, Colombian cocaine cartels, Japanese yakuza, Chinese triads and Central American gangs such as Salvadoran Mara Salvatrucha (MS-13). What happens now is similar to what happened in the nineteenth and twentieth century with the arrival of immigrants from Europe, Irish, Polish, Russian, Jewish and German among others. And these suffered the first accusations of criminals by the natives.

Since the beginning, the cycles of mass immigration have been accompanied by alarms, threats, warnings, accusations and stereotypes towards newcomers. These periods have taken place during economic recessions or internal crises of the recipient countries (Crash of 1929, after SW II, the crisis of 2001-2002, 2008-2010, etc.). When these massive migratory movements occur, the immigrants come from countries with a different language and culture than the United States, and in some cases, with a different religion. The current situation is no exception. California Proposition 187 (also known as the Save Our State (SOS) initiative), approved in 1994 with 59 percent of the vote (but challenged as unconstitutional and overturned by a federal court), stated in its opening lines that "the people of California ... have suffered and is suffering economic difficulties [and] personal injury and damage caused by the criminal conduct of illegal aliens in this state". However, the government of California declared itself a sanctuary state in collaboration and solidarity with the more than twenty sanctuary cities that comprise it, including San Francisco (Suárez Ávila, 2017). The contradiction regarding Hispanic immigration is constant, in 1994 they were criminals, in 2008 they were necessary and desirable. Hispanic immigration is necessary as long as native workers do not fill low-skilled jobs. How also, those who commit a crime are imprisoned and later deported. But not all Hispanic immigration can be criminalized, by of the behavior of a few.

In an analysis by Ousey and Kubrin (2018) looking for the relationship between crime and immigration between 1994 and 2014, they found that 
this relationship was related to tight spaces, that is, cities (city blocks), censuses, countries and areas metropolitan In addition, when they analyzed these data longitudinally, they observed that crime decreased in immigration. That is to say, with greater immigration, crime did not increase, but decreased.

The libertarian Cato institute (2014) turned to the annual American Community Survey (ACS) and analyzed the percentage of undocumented immigrants in prisons to inmates to data, found that prison rates for natives born in the United States it was 1.53 percent, 0.47 percent for legal immigrants and 0.85 percent for undocumented immigrants. If the violation of immigration law violation was not excluded from the data, then the incarceration rate for undocumented immigrants dropped to 0.5 percent. (Landgrave and Nowrasteh, 2017).

When we take age and gender into account, we find Mexican immigrants, the most numerous Hispanic immigrants to the United States, are in state prisons at an adjusted rate that is not strikingly different from U.S. citizens (Hagan and Palloni, 1999).

Therefore, Hispanic immigrants cannot be accused of criminals and criminals when their crime rates are lower than natives and other immigrants.

\section{Conclusions}

Non-authorized immigrants are more active in religious participation compared to regularized ones. This is in line with what was expressed by Cadge and Ecklund (2006), immigrants who are less integrated into American society are more likely than others to attend religious service regularly.

Congregations support no-authorized immigrants, in many ways: by providing shelter. The main help is teaching English, a necessary if they want to have a good job and to be able to integrate into society. They also receive help in social assistance, health, food, housing rental, clothing, etc. Another important aspect where the churches support this group is legal advice to obtain an authorized residence or stay. They are people with few resources and many of them with low educational level.

The different beliefs help both authorized and unauthorized immigrants. The unauthorized immigrants are the ones who receive the most help because they find themselves in a worse and more complex situation. It should be noted that a significant number of unauthorized immigrants do not receive any help from the churches. This may be because they do not attend churches, they do not know that the churches have this help or that family support is enough. 
Unlike the statement by Massey and Espinoza-Higgings (2011) where they said Multivariate analysis of these data confirm that the most common and immediate response to international migration is a decline, not an increase, in the level of religious participation, in contradiction to the theologizing hypothesis. In our case, there is a high participation of Hispanic immigrants in the church, perhaps because the object of study is different. Their study concerned legalized or nationalized persons and in ours they are unauthorized. Possibly, this circumstance carries a greater religious implication.

The Sanctuaries, new and old, have emerged for the defense of Hispanics, mainly Central Americans, against the waves of deportation that have occurred in recent decades. In the era of the Trump administration, they became more visible, due to the former president's letters against Hispanic immigration. It should be remembered that the Obama administration has been the period with the highest number of deportations. It is necessary to address the issue in detail to know in detail each of the processes.

Immigrants often have jobs that Americans don't want or take. So instead of competing with Americans for work, immigrants tend to complement American workers. The ones that are really affected by new immigrants are the jobs of old immigrants. They must compete with new immigrants for those low-skilled and low-paying jobs.

On the other hand, by interrelating the jobs of immigrants, especially unauthorized ones, with the aid received from the different denominations, it is revealed that, this group can hardly be a competition for natives. Hence, its presence has several positive effects on the US. One, occupy jobs rejected by the natives, and necessary for the productive development of the country. Two, increase the birth rate avoiding population aging. Finally, they are generators of wealth, favoring the world leadership of the US.

Another negative assessment against unauthorized immigration is that the US is blamed for the problems, in addition to accusing them of not paying taxes. The reality is quite different, this group pays taxes that will never reverse on them. Every time they buy taxable goods, they are doing it. They contribute to property taxes, the main source of school financing. Similarly, when they buy or rent a house or apartment. A report from the Institute of Taxation and Economic Policy in 2017, It emphasized that undocumented immigrants paid approximately $\$ 12.01$ billion in state and local taxes per year. Just as the Social Security Administration estimated that in 2011, undocumented immigrants and their employers paid about $\$ 14$ billion in payroll taxes just for the benefits they will never get. 
Keep in mind that many of the accusations of undocumented Hispanic immigration crimes are due to the need to blame someone for the failures of US citizenship. What better, to take for it, the most unprotected. As is expressed by Weishar (2018) Nativist politicians scapegoat immigrants and inflate immigrant criminality to manipulate public fears and create support for harsh, anti-immigrant policies. But given these actions, legislators should know that the expulsion of the undocumented Hispanic whose work resides in activities not desired by the natives and poorly paid, can paralyze the country. Before undertaking such a measure, it should be considered whether an unintended and unwanted consequence will occur.

A study conducted by Light, He and Robery (2020) reveals two broad conclusions about the criminality of undocumented immigrants. First, undocumented immigrants have substantially lower rates of crime compared to both native US citizens and legal immigrants. Second, over the $7 \mathrm{y}$ period from 2012 to 2018, the proportion of arrests involving undocumented immigrants in Texas was relatively stable or decreasing.

Nowrasteh (2019), Director of Immigration Studies in Cato Institute, has conducted his own work based on criminal conviction and arrest data in Texas. He found that as a percentage of the population, illegal immigrants amassed 50 percent fewer convictions than native-born Americans, and legal immigrants rated even lower.

This makes it clear that the incrimination of immigrants as distorting elements of American society is false. They have become the scapegoat of political speeches to win votes. As noted, immigration is a value to American society, both economically and socially. It is surprising that many naturalized Hispanics, who were once immigrants, even undocumented, today are against immigration.

It cannot be analyzed from a particular perspective of rejection and contempt for the immigrant. Especially when the data is contrary to the missives launched by politicians and defenders of the WASP nation. Criminalizing a group that leaves their countries due to violence and lack of opportunities. Each case has a different reality, and therefore must be analyzed independently. It cannot be ignored that Hispanic immigrant labor is necessary, due to the rejection of those jobs by those born in the US. If you want to remain a Christian nation, you must accept and protect Hispanics who are raising Christian affiliation rates. Finally, Hispanic immigration cannot be used to hide other problems in America. 
The Hispanic immigration in United States: an analysis of the relationship with the churches ... / J.A. VALERO y A. SÁNCHEZ

\section{REFERENCE}

Acemoğlu, D., 1998, "Why Do New Technologies Complement Skills? Directed Technical Change and Wage Inequality", in Quarterly Journal of Economics 113(4): 1055-1089.

Adkins, Ch., 2014, Slavery and the Civil War in Cultural Memory. Doctoral dissertation. Cambridge, MA. Harvard University.

Ambrosini, M., 2008, "Participación religiosa e integración de los inmigrantes. Una reflexión entre América y Europa, entre historia y actualidad", en Migraciones 23: 11-44.

Ball, M., 2016, Donald Trump and the Politics of Fear, The Atlantic, 09/02/2016. Available at https://www.theatlantic.com/politics/archive/2016/09/donald-trumpand-the-politics-of-fear/498116/. (Accessed 16/08/2019).

Bauder, H., 2016, "Sanctuary Cities: Policies and Practices in International Perspective”, in International Migration 55 (2): 174-187. doi.org/10.1111/imig.12308

BBC, 2019, US immigration: ICE arrests nearly 700 people in Mississippi raids, 08 of August of 2019, available at https://www.bbc.com/news/world-us-canada-49275109. (Accessed September,14/09/2019).

Bezdek, B., 1995, "Religious outlaws: Narratives of legality and the politics of citizen interpretation", in Tennessee Law Review 62: 899-996.

Borjas, G. J., 2017, “The Wage Impact of the Marielitos: A Reappraisal”, in ILR Review, 70(5), 1077-1110. https://doi.org/10.1177/0019793917692945

Cadge, W. y Ecklund, E. H., 2006, "Religious Service Attendance among Immigrants: Evidence from the New Immigrant Survey-Pilot", in American Behavioral Scientist 49(11): 1574-1595.

Chomsky, A., 2007, They Take Our Jobs!: And 20 Other Myths about Immigration, New York. Beacon Press.

Clemens, M. A., Lewis,E. G y Postel, H.M., 2018, "Immigration Restrictions as Active Labor Market Policy: Evidence from the Mexican Bracero Exclusion", in American Economic Review 108(6): 1468-1487.

Caminero-Santangelo, M, 2013, "The voice of the voiceless: religious rhetoric, undocumented immigrants, and the New Sanctuary Movement in the United States", in Lippert, R. K. and Rehaag, S. (eds.) Sanctuary Practices in International Perspectives: Migration, Citizenship and Social Movements. Abingdon, UK, Routledge, pp. 92-105.

Connor, P., 2009a, "International Migration and Religious Participation: The Mediating Impact of Individual and Contextual Factors", in Sociological Forum 24: 779-803.

Connor, P., 2009b, "Immigrant Religiosity in Canada: Multiple Trajectories", in International Migration and Integration 10: 159-175. 
Díaz, H. L. D., 2006, “El desarrollo socioeconómico de los hispanos en los Estados Unidos de América. En busca de una teoría”, en Calvo Buezas, T. (ed.), Hispanos en Estados Unidos, inmigrantes en España: ¿amenaza o nueva civilización? (pp. 100-116). Madrid: Catarata.

Eguizabal, O., 2018, "Spiritual Formation of Believers among Latino Protestant Churches in the United States", in Christian Education Journal, 15(3): 422-446. Doi: $10.1177 / 0739891318804829$

Freeland, G., 2010, "Negotiating place, space and borders: The New Sanctuary Movement", in Latino Studies 8(4): 485-508.

Golden, R. and McConnell, M., 1985, Sanctuary: The New Underground Railroad. New York: Orbis.

González Alonso, C., and Pazmiño Santacruz, M., 2015, "Cálculo e interpretación del Alfa de Cronbach para el caso de validación de la consistencia interna de un cuestionario, con dos posibles escalas tipo Likert", en Revista publicando, 2(1): $62-67$

Hagan, J. y Palloni, A., 1999, "Source: Sociological Criminology and the Mythology of Hispanic Immigration and Crime", in Social Problems 46(4): 617-632.

Hirschman, Ch., 2004, "The Role of Religion in the Origins and Adaptation of Immigrant Groups in the United States", in International Migration Review 38: 1206-1233.

Hirschman, Ch., 2007, “The Impact of Immigration on American Society: Looking Backward to the Future Transit", in Europaeische Revue, Nr, 32: 1-11.

Iannaccone, L. R., 1990, "Religious Practice: A Human Capital Approach", in Journal for the Scientific Study of Religion 29: 297-314.

Kerwin, D., 2017, “The Catholic Church's Commitment to Immigrants and Refugees at the Dawn of the Trump Era", in Center for Migration Studies Spring: 1-3. doi:10.14240/cmsesy011717

Kerwin, D., 2015, “The US Refugee Protection System on the 35th Anniversary of the Refugee Act of 1980", in JMHS, 3(2): 1-50.

Landgrave, M. and Nowrasteh, A., 2015, "Criminal Immigrants: Their Numbers, Demographics, and Countries of Origin (March 15, 2017)", in Immigration Research and Policy Brief No. 1, Available at SSRN: https://ssrn.com/abstract $=2979441$

Levitt, P., 2003, "You know Abraham was really the first immigrant: religion and transnational migration", in International Migration Review 37(3): 847-873.

Light, M.T., He, J., Robey, J.P., 2020, “Comparing crime rates between undocumented immigrants, legal immigrants, and native-born US citizens in Texas", in Proceedings of the National Academy of Sciences 117(51) 32340-32347; DOI:10.1073/pnas.2014704117.

López-Santiago, M., Hernández-Juárez, M., and León-Merino, A., 2017, “La marginación y exclusión como posibles factores socioeconómicos de la violencia ur- 
The Hispanic immigration in United States: an analysis of the relationship with the churches ... / J.A. VALERO y A. SÁNCHEZ

bana: el caso de Valle de Chalco Solidaridad, Estado de México", en Papeles de Población, 23(91). 171-199.

Martínez, J.F., 2018, The history of Latino Protestants in the United States. Grand Rapids, MI: Eerdmans.

Massey, D.S., and Higgins, M. E., 2011, “The Effect of Immigration on Religious Belief and Practice: A Theologizing or Alienating Experience?", in Social science research 40(5): 1371-1389.

doi:10.1016/j.ssresearch.2010.04.012

National Academies of Sciences, Engineering, and Medicine, 2017, The Economic and Fiscal Consequences of Immigration. Washington, DC: The National Academies Press. https://doi.org/10.17226/23550.

Nowrasteh, A., 2019, "Criminal Immigrants in Texas in 2017. Illegal Immigrant Conviction Rates and Arrest Rates for Homicide, Sex Crimes, Larceny, and Other Crimes", in Immigration research and policy brief. 13: 1-7.

Ordorica Mellado, M., and Cervantes-Salas, M., 2021, "El fin de la esperanza: los homicidios como causa de la expectativa de vida Perdida", en Papeles de Población, 26(105), 39-68.

Ottaviano, G, y Peri, G., 2012, "Rethinking the effects of immigration on wages", in Journal of the European Economic Association, 10(1):152-197.

Ousey, G. C, and Kubrin, Ch.E., 2018, "Immigration and Crime: Assessing a Contentious Issue", in Annual Review of Criminology 1(1): 63-84.

Peri, G. and Yasenov, V. 2019, "The Labor Market Effects of a Refugee Wave”, in Journal of Human Resources, vol 54(2): 267-309.

Peri, G, and Sparber, Ch., 2009, "Task Specialization, Immigration, and Wages", in American Economic Journal: Applied Economics 1 (3): 135-69.

Pew Research Center (PRC), 2019, What we know about illegal immigration from Mexico. Retrieved on august, 13, 2019 from https://www.pewresearch.org/facttank/2019/06/28/what-we-know-about-illegal-immigration-from-mexico/ (Accessed 26/08/2019).

Prado Pérez, R. E., 2018, "El entramado de violencias en el Triángulo Norte Centroamericano y las maras”, en Sociológica (México), 33(93), 213-246.

Rivera-Sánchez, L., 2007, “Migrantes entre México y los Estados Unidos: la construcción de espacios públicos desde el campo religioso transnacional”, en Revista Enfoques Ciencia Politica y Administración Pública 7: 253-276.

Sánchez Bayón, A. and Valero-Matas, J. A., 2020, “Persecución religiosa y migratoria en la Posglobalización: estudio de caso estadounidense y la deconstrucción de sus pilares fundacionales", en Lurralde: Investigación y espacio, 43: 61-88.

Seifert, T., Hervás Gómez, C., and Toledo Morales, P., 2019, “Diseño y validación del cuestionario sobre percepciones y actitudes hacia el aprendizaje por dispositivos móviles", Pixel -Bit: Revista de medios y Educación, 54: 45-64. 
Shoemaker, K., 2013, "Sanctuary for crime in the early common law", in R.K. Lippert and S. Rehaag (Eds) Sanctuary Practices in International Perspectives: Migration, Citizenship and Social Movements. Abingdon, UK, Routledge.

Smith, T. L., 1978, "Religion and Ethnicity in America", in American Historical Review 83:1115-85.

Smith, Ch.; Sikkink, D. and Bailey, J., 1998, "Devotion in Dixie and Beyond: A Test of the 'Shibley Thesis' on the Effects of Regional Origin and Migration on individual Religiosity", in Journal for the Scientific Study of Religion 37: 494-506.

Suárez Ávila, P. V., 2017, “Ciudades santuario de California: la acción política de los gobiernos locales en la política pública migratoria contemporánea de Estados Unidos", en Migración y desarrollo, 15(29): 51-70.

Summers, S., 2018, "Why Immigration Is First About Families, Not Economics or Security", in Public Justice Review, 8: 1-3

Tavakol, M., and Dennick, R., 2011, "Making sense of Cronbach's alpha", in International journal of medical education, 2: 53-55

Valero-Matas, J, A. and Sánchez, A., 2018, "Relaciones de la inmigración hispana con la Iglesia en el área de Washington D. C., Virginia y Maryland”, en Migraciones. Publicación del Instituto Universitario de Estudios sobre Migraciones, 45: 89-117. doi:https://doi.org/10.14422/mig.i45.y2018.004

Walia, H., 2014, "Sanctuary City from below: dismantling the colonial city of Vancouver", in The Mainlander, available at http://themainlander.com/2014/06/02/ sanctuary-city-from-below-dismantling-the-city-of-vancouver/ (accessed 3/09/2019).

Warner, R. S., 1997, "Religion, Boundaries, and Bridges", in Sociology of Religion 58: 217-239.

Weishar, S. 2018, "Immigrant and Crime: Debunking the Myth", in Just South Quarterly Spring:6-7.

\section{CURRICULAR INFORMATION OF THE AUTHORS}

Jesús Alberto Valero Matas

Profesor Titular de Sociología en la Universidad de Valladolid, Doctor en Sociología y Licenciado en Sociología y Licenciado en Ciencias Políticas y de la Administración. Master en Ciencia Políticas y Derecho Constitucional. Ha dirigido diferentes proyectos de investigación. Tiene en su haber más de 100 artículos en revistas indexadas nacionales e internacionales, 15 monografías y 30 capítulos de libro. Ha sido investigador visitante en diversas universidades extranjeras como The University of Edimburg. University of Auckland, Ben Gurion Univerity, Georgetown University, Colorado School of Mines entre otras. Y profesor Visitante, UNAM, Ins- 
tituto Politécnico de Braganza, Universidad de Santiago de Compostela, Catholic University of America, entre otras. Sus principales líneas de investigación son: la sociología de la educación, análisis y estudio de los aprendizajes científicos. Sociología de la religión, sociología de la ciencia y sociología de los movimientos migratorios.

Dirección electrónica: javaleromatas@gmail.com

Registro ORCID: https://orcid.org/ 0000-0002-7330-1635

Antonio Sánchez Bayón

Doctor en Derecho por la Universidad Complutense de Madrid y en Humanidades por la Universidad de Murcia (doctorando en RR.II. por Univ. Valladolid). Prof. Titular en CC. Sociales y Jurídicas (ANECA), con sexenios (CNEAI) y autoridad internacional (VIAF). Actualmente es docente en ISEMCO, EAE, UNIR y en la Universidad Bernardo OHiggins (Chile), impartiendo asignaturas de Fundamentos político-jurídicos y protocolarias, así como de Recursos Humanos (sobre todo gestión cultural y generacional). Ha sido académico visitante en universidades europeas y americanas (v.g. Harvard, Baylor, DePaul), consultor y abogado en ejercicio (ICAM), además de colaborador en diversos medios de comunicación. Cuenta con una rica y premiada producción científico-académica (más de 40 libros y 60 artículos, casi 100 ponencias y cursos especializados, 10 tesis dirigidas, etc.).

Dirección electrónica: antonio_sanchez_bayon@hotmail.com 